\title{
Maternal risk factors associated with low birth weight in Karachi: a case-control study
}

S.A. Rizvi, ${ }^{1}$ J. Hatcher, ${ }^{1}$ I. Jehan ${ }^{1}$ and R. Qureshi ${ }^{2}$

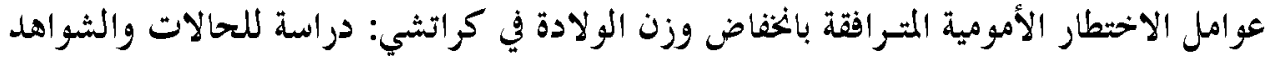

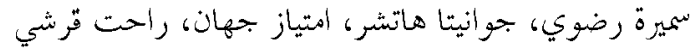

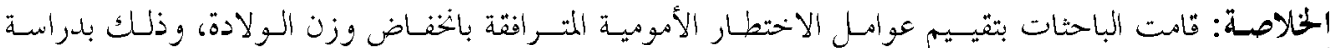

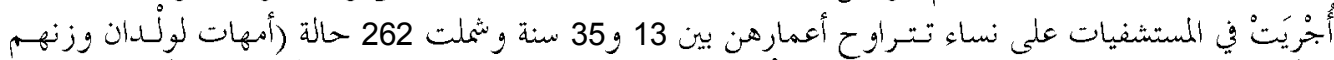

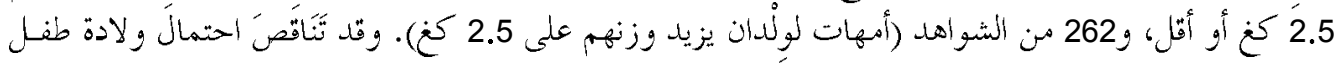

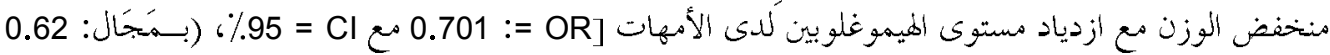

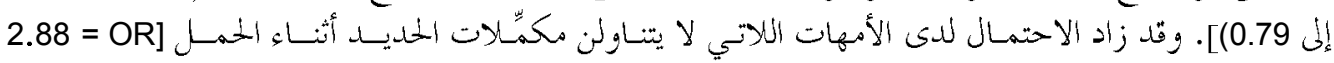

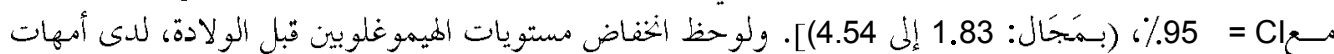
الأطفال المنخفضي وزن الولادة. (المان.

ABSTRACT To evaluate maternal risk factors associated with low birth weight (LBW) among women aged 15-35 years, we carried out a hospital-based, case-control study on 262 cases (mothers of neonates weighing $\leq 2.5 \mathrm{~kg}$ ) and 262 controls (mothers of neonates weighing $>2.5 \mathrm{~kg}$ ). Odds of delivering a low-birth-weight baby decreased with increase in maternal haemoglobin [odds ratio (OR): 0.701; 95\% confidence interval $(\mathrm{Cl}): 0.62-0.79]$. Odds were greater among mothers not using iron supplements during pregnancy (OR: 2.88; 95\% Cl: 1.83-4.54). Mothers of LBW babies had lower haemoglobin levels before delivery.

Facteurs de risque maternels associés à un faible poids de naissance à Karachi : une étude cas-témoins

RÉSUMÉ Afin d'évaluer les facteurs de risque associés à un faible poids de naissance chez les femmes âgées de 15 à 35 ans, nous avons réalisé une étude cas-témoins en milieu hospitalier auprès d'un échantillon de 262 cas (mères de nouveau-nés pesant au maximum à la naissance $2,5 \mathrm{~kg}$ ) et de 262 témoins (ayant accouché d'enfants d'un poids supérieur à 2,5 kg). La probabilité de mise au monde d'un enfant de faible poids de naissance diminue proportionnellement à l'augmentation de l'hémoglobinémie maternelle (odds ratio [OR] : 0,701; intervalle de confiance à $95 \%\left[{ }_{1} C_{95} \%: 0,62-0,79\right.$ ). Cette probabilité est d'autant plus grande que les mères n'utilisent pas de supplémentation en fer pendant la grossesse (OR : 2,$\left.88 ; I C_{95}: 1,83-4,54\right)$. Les mères de nourrissons de faible poids de naissance présentaient avant l'accouchement une hémoglobinémie basse.

${ }^{1}$ Department of Community Health Sciences; ${ }^{2}$ Department of Obstetrics and Gynaecology, Aga Khan University, Karachi, Pakistan (Correspondence to S.A. Rizvi: sameera.rizvi@aku.edu).

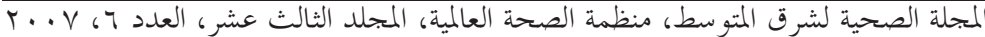




\section{Introduction}

Low birth weight (LBW) is a potentially preventable public health problem particularly prevalent in developing countries [1]. It contributes substantially to neonatal, infant and childhood mortality as well as to morbidity [2]. In addition, the weight of an infant at birth is an important indicator of maternal health and nutrition prior to and during pregnancy.

Striking variation exists in LBW prevalence within Asia: the highest rates are in South Asia and the lowest in East Asia [3]. In East Asia, the proportion of LBW ranges from $5 \%$ to $10 \%$, with the exception of Thailand, where an estimated $36 \%$ of all infants are LBW [4]. In South Asia, the problem is most acute with up to $50 \%$ of all neonates having LBW [3]. Up to $25 \%$ of neonates in Pakistan are classed as LBW [5].

Infants with LBW have higher rates of morbidity and mortality from infectious disease, malnutrition and growth failure and are also more likely to have abnormal cognitive development, neurological impairment and poor school performance $[6,7]$. These babies are at greater risk of cardiovascular disease, hypertension and diabetes in adult life $[8-11]$.

There are numerous factors contributing to LBW, both maternal and fetal. The maternal risk factors are biologically and socially interrelated; most are, however, modifiable.

In Pakistan, statistics are available, national nutrition surveys are carried out and the prevalence of LBW has been estimated at $12 \%-25 \%$ [5]. There has, however, been very little research done on risk factors of LBW among women aged 15-35 years. This group is not biologically at high risk, but as most childbearing occurs in this age range, preventable risk factors among this group need to be assessed. It would be espe- cially beneficial to identify factors that are modifiable among this group of women.

The objective of the study was to identify the maternal risk factors associated with LBW among women aged 15-35 years in hospital births in Karachi.

\section{Methods}

We carried out a hospital-based casecontrol study on LBW in Karachi in the maternity wards of 3 hospitals that provide health services to the lower socioeconomic strata, to study risk factors of LBW among those of underprivileged social status. Each of these hospitals hosts about 3500 deliveries per year. Patients are drawn from urban, suburban and rural areas, and about $75 \%$ of users are classified as living in poverty. Civil Hospital, a 1400 bed hospital, is a general hospital working under the Sind government. This hospital is attached to Dow Medical College, Karachi. Jinnah Postgraduate Medical Centre is a federal government general hospital attached to Sind Medical College, Karachi. Lady Dufferin Hospital is a charity hospital for women and children, mainly catering to the needs of low-income families living in nearby Lyari, Shershah and other places in the Old City area. It began with 25 beds and it now has over 200 beds. In 2003 over 4000 deliveries were carried out there.

The high uptake of services at these hospitals is probably owing to their low cost. After admission, the majority of births take place within 2 days. The hospital stay is usually 1 day after delivery unless the mother or infant experience problems.

The study data were collected between July 2003 and September 2003 by trained interviewers by interviews with the mothers, abstraction of medical records and anthropometry. 
Birth weight $\leq 2.5 \mathrm{~kg}$ was defined as LBW in this study. Cases were defined as mothers of LBW neonates while controls were mothers of neonates weighing $>2.5 \mathrm{~kg}$ at the time of birth. This modification in the definition of LBW (birth weight $<2.5 \mathrm{~kg}$ ) was adopted to avoid digit preference, i.e. a tendency in the observers to record a weight of $2.4 \mathrm{~kg}$ as $2.5 \mathrm{~kg}$ [12]. Controls were identified from birth records as the next eligible delivery of a non-LBW baby after a woman delivered an LBW baby.

Sample size was calculated using the method of Schlesselman for an unmatched case-control study [13] to detect the odds ratio (OR) of 2.0 , power of $90 \%$, specifying alpha at $5 \%$ with $22 \%$ prevalence of antenatal care (ANC) [14] and estimating the non-responders at $10 \%$.

A total of 262 cases (vaginal delivery or caesarean section) and 262 controls of age 15-35 years with no known medical illness who delivered a live-born singleton baby through without congenital malformation and with gestational age 37-42 weeks were enrolled from hospital records within 1 day of delivery. Mothers with a known chronic illness (hypertension, tuberculosis, diabetes mellitus), or who had multiple births or delivered babies with congenital abnormalities were excluded. Only 10 women were excluded: 3 had twin pregnancies, 2 were $>35$ years, 3 did not give consent, 1 had tuberculosis and 1 was 14 years old.

A pre-coded questionnaire was developed in English, translated into Urdu and then back-translated into English to check the phrasing to ensure that that the sense of the questions was not changed. Information was taken from interviews with mothers, medical records and post-partum maternal examination. Hospital records were used to identify cases. For every case selected, the next woman who delivered a non-LBW baby on the same date was selected as a control. Mothers were enrolled on a daily basis. The response rate was almost $99 \%$. Only 3 mothers refused to participate (did not give consent) in the study. The reason for this was that they had delivered by caesarean section and at the time of interview they were in pain. Out of these 3 mothers, 1 had delivered a LBW baby.

Study information included demographic data, socioeconomic status, previous pregnancies, ANC during current pregnancy, morbidity during pregnancy, maternal nutritional status, strenuous physical activity and smoking. Socioeconomic status was assessed by employment of the mother and her spouse, mean household size, monthly household income and house type. In Pakistan house types are pucca (cemented), kutcha (mud houses) and kutcha pucca (made with asbestos sheets). The pucca houses are a sign of higher socioeconomic status. Maternal age was recorded as a continuous variable as completed years. Age was confirmed from the mother through interview, from her national identity card as well as from the hospital records. In case of disparity, the national identity card was used. Education status of both parents was coded to distinguish between parents who had received no school education (illiterate), had primary school education ( $<6$ years) or had completed secondary school ( $\geq 6$ years). Parity was analysed as a continuous variable. History of abortion was classified as ever/never had abortion. Birth interval between the current and last pregnancy was taken as a continuous variable. Total numbers of ANC visits for the current pregnancy were categorized as $\geq 4$ visits and $<4$ visits, based on the World Health Organization (WHO) and UNICEF criteria that women should have $\geq 4$ ANC visits with an appropriate health care provider [15]. Information given by the ANC provider was considered adequate

المجلة الصحية لشرق المتوسط، منظمة الصحة العالمية، المجلد الثالث عشر، العدد Y، V... 
if the provider discussed the importance of healthy food and breastfeeding, weight gain during pregnancy, early labour and future family planning with the mother.

Maternal nutritional status was assessed by postpartum weight, haemoglobin level before delivery, and food consumption before and during pregnancy. Maternal haemoglobin was analysed as a continuous variable.

Use of iron and calcium supplements during pregnancy was dichotomized into daily and not daily. An account of a typical day spent by the mother was taken. This included travelling on foot, washing clothes by hand, sweeping floors and midday rest. These variables were categorized into every day, 3 times a week and once a week.

Information about maternal haemoglobin, gestational age and morbidity during pregnancy was taken from the hospital records. Gestational age was calculated from the menstrual history or an ultrasound result if available. The expected date of each delivery was calculated from the menstrual history provided the dates were sure and the menstrual cycles regular and there was no history of use of oral contraceptives in the 3 months before conception. If any of the above criteria were not met then the results of the ultrasound scan, if available, were used to calculate the expected date of delivery.

Ethical approval for the study was taken from the Aga Khan University Ethical Review Committee.

\section{Statistical analysis}

Logistic regression was used to identify the factors associated with LBW using SPSS, version 10. Descriptive statistics were computed for all variables according to type. Frequency, mean and standard deviation were obtained for continuous variables while the categorical variable was assessed by computing frequencies. Crude odds ratio (OR) and 95\% confidence interval (CI) for each variable of interest were calculated. $P$-values were calculated by likelihood ratio test for the significance of the beta coefficients; $P \leq 0.05$ was considered significant for all the independent variables in the model. Multiple logistic regression analysis was performed to identify factors associated with LBW, while adjusting for other variables.

Data gathered from the study were analysed according to WHO definition of LBW $(<2.5 \mathrm{~kg})$ as well as $\leq 2.5 \mathrm{~kg}$ and it was found that the results were similar. Therefore, the original definition of $\leq 2.5$ $\mathrm{kg}$ was used because the power of the study would have been reduced if the definition was changed. All analyses discussed were based on $\leq 2.5 \mathrm{~kg}$.

\section{Results}

With regard to demographic and socioeconomic characteristics controls appeared to have better housing conditions while household income was similar among the 2 groups (Table 1). Cases and their husbands were less educated than the controls (Table 1) but the difference was only significant for the mothers $(P=0.007)$.

During the current pregnancy, a high percentage of both cases (96.9\%) and controls $(90.5 \%)$ received appropriate ANC (Table $2)$. The ANC experience of the mothers in the control group was slightly better than that of cases. Mean number of ANC visits was 4.3 [standard deviation (SD) 1.4] for cases and 3.8 (SD 1.8) for controls ( $P=$ 0.002).

Although both cases and controls were physically active during pregnancy, a greater proportion of women in the control group had a daily midday rest $(P=0.044)$ (Table 


\begin{tabular}{|c|c|c|c|c|c|c|c|}
\hline \multirow[t]{2}{*}{ Variable } & \multicolumn{2}{|c|}{$\begin{array}{c}\text { Cases } \\
(n=262)\end{array}$} & \multicolumn{2}{|c|}{$\begin{array}{l}\text { Controls } \\
(n=262)\end{array}$} & \multirow[t]{2}{*}{ OR } & \multirow[t]{2}{*}{$95 \% \mathrm{Cl}$} & \multirow[t]{2}{*}{$P$-value } \\
\hline & No. & $\%$ & No. & $\%$ & & & \\
\hline \multicolumn{8}{|c|}{ Maternal education (years) } \\
\hline$\geq 6$ & 101 & 38.5 & 117 & 44.6 & 1.00 & - & 0.007 \\
\hline$<6$ & 44 & 16.7 & 62 & 23.6 & 0.82 & $0.51-1.31$ & \\
\hline Illiterate & 117 & 44.6 & 83 & 31.6 & 1.63 & $1.12-2.45$ & \\
\hline \multicolumn{8}{|l|}{ Maternal occupation } \\
\hline Housewife & 249 & 95.0 & 254 & 96.9 & 1.00 & - & 0.270 \\
\hline Employed & 13 & 5.0 & 8 & 3.1 & 1.65 & $0.67-4.06$ & \\
\hline \multicolumn{8}{|l|}{ Paternal education (years) } \\
\hline$\geq 6$ & 128 & 48.9 & 142 & 54.2 & 1.00 & - & 0.201 \\
\hline$<6$ & 28 & 10.7 & 33 & 12.6 & 0.95 & $0.54-1.66$ & \\
\hline Illiterate & 106 & 40.5 & 87 & 33.2 & 1.37 & $0.94-1.98$ & \\
\hline \multicolumn{8}{|l|}{ Paternal occupation } \\
\hline Business & 220 & 84.0 & 218 & 83.2 & 1.00 & - & 0.896 \\
\hline Government & 37 & 14.0 & 40 & 15.2 & 0.92 & $0.57-1.50$ & \\
\hline Unemployed & 5 & 1.9 & 4 & 1.5 & 1.25 & $0.33-4.07$ & \\
\hline \multicolumn{8}{|l|}{ Type of house } \\
\hline Pucca & 196 & 74.9 & 215 & 82.1 & 1.00 & - & 0.037 \\
\hline Kutcha pucca & 33 & 12.5 & 31 & 11.8 & 1.77 & $0.69-1.99$ & \\
\hline \multirow[t]{2}{*}{ Kutcha } & 33 & 12.5 & 16 & 6.1 & 2.28 & $1.21-4.27$ & \\
\hline & Mean & SD & Mean & SD & & & \\
\hline Maternal age (years) & 24.8 & 4.7 & 25.3 & 4.5 & - & & 0.135 \\
\hline Monthly family income $e^{b}$ & 5019 & 2517 & 4690 & 2596 & - & & 0.129 \\
\hline Household size & 7.7 & 4.3 & 7.8 & 4.2 & - & & 0.870 \\
\hline
\end{tabular}

${ }^{a}$ Kutcha $=$ mud house $;$ pucca $=$ cement house, Kutcha pucca $=$ made with asbestos sheets. ${ }^{b}$ Pakistan rupees; US $\$ 1 \approx 60$ Pakistan rupees 2003.

$O R=$ odds ratio; $\mathrm{Cl}=$ confidence interval; $S D=$ standard deviation

3). Mean duration of the midday rest was 142 (SD 90) minutes for mothers of LBW babies and 148 (SD 103) minutes for the control group $(P=0.493)$.

The haemoglobin status and daily intake of iron supplements was significantly better among the control group $(P<0.001)$ (Tables 2 and 4).

The final logistic regression model included maternal haemoglobin before delivery, iron supplement intake of mother, maternal post-partum weight and maternal age. After adjusting for the effect of other variables in the model it was found that maternal haemoglobin level (measured before delivery) was independently associated with LBW (Table 4). Odds of delivering an LBW baby decreased with increase in maternal haemoglobin (OR: 0.70; 95\% CI: $0.63-0.79)$. Mothers who did not take iron supplements during pregnancy had increased odds of having an LBW baby (OR:

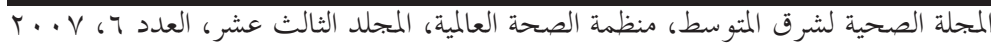




\begin{tabular}{|c|c|c|c|c|c|c|c|}
\hline \multirow[t]{2}{*}{ Variable } & \multicolumn{2}{|c|}{$\begin{array}{c}\text { Cases } \\
(n=262)\end{array}$} & \multicolumn{2}{|c|}{$\begin{array}{l}\text { Controls } \\
(n=262)\end{array}$} & \multirow[t]{2}{*}{ OR } & \multirow[t]{2}{*}{$95 \% \mathrm{Cl}$} & \multirow[t]{2}{*}{$\overline{P \text {-value }}$} \\
\hline & No. & $\%$ & No. & $\%$ & & & \\
\hline \multicolumn{8}{|l|}{ Appropriate ANC } \\
\hline$\geq 4$ visits & 254 & 96.9 & 237 & 90.5 & 1.00 & - & 0.053 \\
\hline$<4$ visits & 8 & 3.1 & 25 & 9.5 & 3.37 & $1.49-7.63$ & \\
\hline \multicolumn{8}{|l|}{ ANC provider } \\
\hline Doctor & 219 & 83.6 & 247 & 94.2 & 1.00 & - & 0.094 \\
\hline Dai & 18 & 6.9 & 7 & 2.8 & 2.42 & $1.02-5.72$ & \\
\hline No ANC & 25 & 9.5 & 8 & 3.0 & 3.56 & $1.57-8.06$ & \\
\hline \multicolumn{8}{|c|}{$\begin{array}{l}\text { Information provided by ANC } \\
\text { provider }\end{array}$} \\
\hline Adequate & 99 & 37.8 & 107 & 40.8 & 1.00 & - & 0.519 \\
\hline No information & 163 & 62.2 & 155 & 59.2 & 1.12 & $0.79-1.59$ & \\
\hline \multicolumn{8}{|c|}{$\begin{array}{l}\text { Antitetanus toxoid vaccination } \\
\text { during pregnancy }\end{array}$} \\
\hline Received & 217 & 82.8 & 237 & 90.5 & 1.00 & - & 0.026 \\
\hline Not received & 44 & 16.8 & 25 & 9.5 & 1.80 & $1.07-3.04$ & \\
\hline \multicolumn{8}{|c|}{ Daily iron supplement } \\
\hline Yes & 176 & 67.1 & 223 & 85.1 & 1.00 & - & $<0.001$ \\
\hline No & 86 & 32.8 & 39 & 14.9 & 2.82 & $1.84-4.32$ & \\
\hline \multicolumn{8}{|c|}{ Daily calcium supplement } \\
\hline Yes & 211 & 80.5 & 245 & 93.5 & 1.00 & - & 0.053 \\
\hline No & 51 & 19.5 & 17 & 6.5 & 2.51 & $1.97-6.27$ & \\
\hline
\end{tabular}

2.88; 95\% CI: 1.83-4.54). With increase in maternal post-partum weight, odds decreased (OR: 0.97; 95\% CI: 0.95-0.99).

\section{Discussion}

In the present study the relationships between LBW and maternal haemoglobin status, iron supplement intake and post-partum weight were found to be statistically significant. All these factors are interrelated.

A strong relationship was found between anaemia and LBW [16]. The findings were in agreement with other studies of anaemic pregnant women carried out in Pakistan $[17,18]$ and Syria [19]. Women can develop iron deficiency anaemia from the loss of blood during menstruation and from repeated pregnancies; it can also be caused by a lack of iron in the diet. During pregnancy, women may develop anaemia because the growing fetus draws upon the mother's iron for the development of red blood cells and other tissues.

Due to the natural decrease in haemoglobin level during pregnancy, the haematocrit measurement should be carried out prior to pregnancy. In the present study, 
Table 3 Univariate analysis showing the association of low birth weight with strenuous physical activity during pregnancy among mothers aged 15-35 years in hospital births in Karachi, Pakistan, July-September 2003

\begin{tabular}{|c|c|c|c|c|c|c|c|}
\hline \multirow[t]{2}{*}{ Variable } & \multicolumn{2}{|c|}{$\begin{array}{c}\text { Cases } \\
(n=262)\end{array}$} & \multicolumn{2}{|c|}{$\begin{array}{l}\text { Controls } \\
(n=262)\end{array}$} & \multirow[t]{2}{*}{ OR } & \multirow[t]{2}{*}{$95 \% \mathrm{Cl}$} & \multirow[t]{2}{*}{$P$-value } \\
\hline & No. & $\%$ & No. & $\%$ & & & \\
\hline \multicolumn{8}{|l|}{ Walk for 30 minutes } \\
\hline Never & 46 & 17.6 & 56 & 21.3 & 1.00 & - & 0.737 \\
\hline Once a week & 67 & 25.6 & 62 & 23.7 & 1.22 & $0.77-1.94$ & \\
\hline 2 times a week & 21 & 8.0 & 19 & 7.3 & 1.31 & $0.78-2.20$ & \\
\hline Every day & 128 & 48.8 & 125 & 47.7 & 1.34 & $0.64-2.80$ & \\
\hline \multicolumn{8}{|c|}{ Washing clothes by hand } \\
\hline Never & 19 & 7.3 & 24 & 9.1 & 1.00 & - & 0.004 \\
\hline Once a week & 47 & 17.9 & 73 & 27.9 & 0.81 & $0.40-1.64$ & \\
\hline 2 times a week & 73 & 27.9 & 82 & 32.4 & 1.12 & $0.57-2.21$ & \\
\hline Every day & 123 & 47.0 & 83 & 31.6 & 1.83 & $0.94-3.56$ & \\
\hline \multicolumn{8}{|l|}{ Floor sweeping } \\
\hline Never & 25 & 9.5 & 23 & 8.8 & 1.00 & - & 0.930 \\
\hline Once a week & 2 & 0.8 & 1 & 0.4 & 0.90 & $0.15-21.67$ & \\
\hline 2 times a week & 1 & 0.4 & 1 & 0.4 & 0.92 & $0.05-15.57$ & \\
\hline Every day & 234 & 89.3 & 237 & 90.4 & 1.84 & $0.49-1.63$ & \\
\hline \multicolumn{8}{|l|}{ Midday rest } \\
\hline Every day & 210 & 80.1 & 226 & 86.2 & 1.00 & - & 0.044 \\
\hline 2 times a week & 27 & 10.3 & 10 & 3.8 & 0.99 & $0.53-1.84$ & \\
\hline Once a week & 4 & 1.5 & 3 & 1.14 & 1.44 & $0.32-6.34$ & \\
\hline Never & 21 & 8.0 & 23 & 8.0 & 2.92 & $1.38-6.19$ & \\
\hline
\end{tabular}

Table 4 Final multiple logistic regression model showing association of low birth weight with maternal haemoglobin, daily iron supplement intake, maternal post-partum weight and maternal age among mothers aged 15-35 years in hospital births in Karachi, Pakistan, JulySeptember 2003

\begin{tabular}{|c|c|c|c|c|c|c|c|}
\hline \multirow[t]{2}{*}{ Variables } & \multicolumn{2}{|c|}{$\begin{array}{c}\text { Cases } \\
(n=262)\end{array}$} & \multicolumn{2}{|c|}{$\begin{array}{l}\text { Controls } \\
(n=262)\end{array}$} & \multirow[t]{2}{*}{$\begin{array}{c}\text { Adjusted } \\
\text { OR }\end{array}$} & \multirow[t]{2}{*}{$95 \% \mathrm{Cl}$} & \multirow[t]{2}{*}{$P$-value } \\
\hline & Mean & SD & Mean & SD & & & \\
\hline \multicolumn{8}{|l|}{ Maternal haemoglobin before } \\
\hline delivery $(g / d L)$ & 9.4 & 1.7 & 10.6 & 1.4 & 0.70 & $0.62-0.79$ & $<0.001$ \\
\hline Post-partum maternal weight $(\mathrm{kg})$ & 55.8 & 9.5 & 57.5 & 10.2 & 0.97 & $0.95-0.99$ & 0.031 \\
\hline \multirow[t]{2}{*}{ Maternal age (years) } & 24.8 & 4.7 & 25.3 & 4.5 & 1.03 & $0.98-1.07$ & 0.153 \\
\hline & No. & $\%$ & No. & $\%$ & & & \\
\hline \multicolumn{8}{|l|}{ Daily iron supplement } \\
\hline Yes & 176 & 67.1 & 223 & 85.1 & 1.00 & - & $<0.001$ \\
\hline No & 86 & 32.8 & 39 & 14.9 & 2.88 & $1.83-4.54$ & \\
\hline
\end{tabular}

$\mathrm{OR}=$ odds ratio; $\mathrm{Cl}=$ confidence interval; $S D=$ standard deviation . 
since the pre-pregnancy haemoglobin levels were not available, the haemoglobin levels were taken from the hospital records which measured the maternal haemoglobin at the time of admission for delivery. It was, thus, not possible to conclude whether the mothers became anaemic at some stage in pregnancy or they were already anaemic before getting pregnant.

Intake of iron supplements during pregnancy was also found to have a protective effect with respect to LBW. This is consistent with the findings of some other studies on iron supplementation and pregnancy outcome [20-22]. Iron supplementation during pregnancy protects a woman from becoming anaemic because the required amounts may not be supplied from dietary intake during this period.

In view of the fact that for the present study the pre-pregnancy weight and weight gain during pregnancy were not available, the post-partum weights were taken. The maternal post-partum weight was also found to be associated with the birth weight of the baby. This is in accordance with a study conducted in Cleveland, Ohio [23].

Our results showed that the risk of LBW increased to some extent with increasing maternal age. This was consistent with results from a number of other studies [24-27]. In Pakistan women generally get married early and begin childbearing soon after marriage. They are expected to have a high total fertility rate. Due to repeated pregnancies and short pregnancy intervals, the risk of having an LBW baby increases in older, grand multiparous women [28].

\section{Limitations of the study}

There were a number of limitations to this study. The international definition of LBW was not used. This criterion was adopted in order to resolve the problem of digit preference. Since maternal age, date of last menstrual period and ANC were determined from the mother, these variables may have been subject to recall bias. Due to logistic constraints maternal pre-pregnancy weight, weight gain during pregnancy and haemoglobin level before pregnancy could not be measured. This was a hospital-based study, while in Pakistan a large number of deliveries are conducted at home and only those neonates that are born in hospital are weighed, a small proportion of all births. Information regarding smoking status of the mother could not be analysed because altogether only 6 mothers admitted that they were smokers.

\section{Conclusion}

An important measure that can be taken to reduce anaemia in pregnancy is to determine whether a woman is anaemic before pregnancy. Haemoglobin assessments should be done in the early stages of pregnancy. In order to prevent anaemia during pregnancy, mothers should be advised to take iron supplements during pregnancy. For appropriate weight gain during pregnancy, pregnant women need to be counselled about a healthy diet. Weight before pregnancy as well as weight gain during pregnancy should be carefully monitored to promote optimal outcomes for mother and infant.

The problem of LBW in Pakistan needs focused attention, and research requires innovative strategies to attempt to identify protective factors among women who are at high risk.

\section{Acknowledgements}

We wish to acknowledge the International Maternal and Child Health Research Training Programme (FIC, NIH \# 5 D43 
TW05497-03) of the Aga Khan University and the University of Alabama at Birming- ham for providing technical support in the development of this manuscript.

\section{References}

1. Singh D. Birthweight: a community perspective. Indian journal of maternal and child health, 1994, 5(2):31-2.

2. Wilcox AJ, Skaeven R. Birthweight and perinatal mortality: the effect of gestational age. American journal of public health, 1992, 82(3):378-83.

3. Fuchs GJ. Low birthweight. In: Global Forum for Health Research-Annual Report 10/90, 2001-02. Geneva, Global Forum for Health Research, 2002 (http:// www.globalforumhealth.org/Non_compliant_pages/forum3/Forum3doc326.htm, accessed 20 June 2004).

4. WHO. Division of Family Health. The incidence of low birth weight: a critical review of available information. World health statistics quarterly, 1980, 33:197-224.

5. Khan N, Jamal M. Maternal risk factors associated with low birthweight. Journal of the College of Physicians and Surgeons of Pakistan, 2003, 13(1):25-8.

6. Ellenberg J, Nelson KB. Birthweight and gestational age in children with cerebral palsy or seizure disorders. American journal of diseases of children, 1979, 133:1044-8.

7. McCormick MC, Gortmaker SL, Sobol AM. Low birthweight children: behavior problems and school difficulties in a national sample. Journal of pediatrics, 1990 , 117:687-93.

8. Barker DJP. Mothers, babies, and disease in later life. London, BMJ Publishing Group, 1994.

9. Barker DJP. Fetal origins of coronary heart disease. British medical journal, 1995, 1:171-4.
10. Suzuki T et al. Relationship between birthweight and cardiovascular risk factors in Japanese young adults. American journal of hypertension, 2000, 13(8):907-13.

11. Longo-Mbenza $B$ et al. Low birthweight and risk of hypertension in African school children. Journal of cardiovascular risk, 1999, 6(5):311-4.

12. Edouard L, Senthilselvan A. Observer error and birthweight: digit preference in recording. Public health, 1997, 111:77-9.

13. Schlesselman JJ. Case-control studies: design, conduct, analysis. Oxford, Oxford University Press, 1982.

14. Antenatal care. New York, UNICEF Childinfo, 2006 (http://www.childinfo.org/areas/ antenatal/, accessed 1 June 2007).

15. Prevention and care of illness. Neonates and infants: 12 key family practices. Geneva, World Health Organization, 2004 (http://www.who.int/child-adolescenthealth/PREVENTION/12_key.htm, accessed 29 March 2007).

16. Malhotra $M$ et al. Maternal and perinatal outcome in varying degrees of anemia. International journal of gynecology and obstetrics, 2002, 79(2):93-100.

17. Khan MM. Effect of maternal anaemia on fetal parameters. Journal of Ayub Medical College, Abbottabad, 2001, 13(2):38-41.

18. Lone FW, Qureshi RN, Emanuel F. Maternal anaemia and its impact on perinatal outcome in a tertiary care hospital in Pakistan. Tropical medicine \& international health, 2004, 4(9):486-9.

19. Wannous S, Arous S. Incidence and determinants of low birth weight in Syrian

المجلة الصحية لشرق المتو سط، منظمة الصحة العالمية، المجلد الثالث عشر، العدد Y، V... 
government hospitals. Eastern Mediterranean health journal, 2001, 7(6):966-74.

20. Hess SY et al. A national survey of iron and folate status in pregnant women in Switzerland. International journal for vitamin and nutrition research, 2001 , 71(5):268-73.

21. Allen LH. Anemia and iron deficiency: effects on pregnancy outcome. American journal of clinical nutrition, 2000, 71(5 suppl.):1280-4S.

22. Christian $P$ et al. Effects of alternative maternal micronutrient supplements on LBW in rural Nepal: double blind randomised community trial. British medical journal, 2003, 326(15):1-6.

23. Ehrenberg $\mathrm{HM}$ et al. Low maternal weight, failure to thrive in pregnancy, and adverse pregnancy outcomes. American journal of obstetrics and gynecology, 2003, 189(6):1726-31.
24. Tin TT et al. Maternal influences on low birthweight. Malaysian journal of reproductive health, 1994, 12(1):32-7.

25. Romero-Maldonado $S$ et al. Efecto de riesgo en el hijo de madre con edad avanzada (estudio de casos y controles) [Effect of risk on the child of an older mother (case-control study)]. Ginecología y obstetricia de México, 2002, 70:295-302.

26. Dickute $\mathrm{J}$ et al. [Do maternal social factors, health behavior and work conditions during pregnancy increase the risk of low birthweight in Lithuania]. Medicina (Kaunas), 2002, 38(3):321-32 [in Lithuanian].

27. Rich-Edwards JW et al. Diverging associations of maternal age with LBW for black and white mothers. International journal of epidemiology, 2003, 32(1):83-90. 